\title{
Developing Alternative Sources of Funding Local Governments in Nigeria during Period of Global Economic Recession
}

\author{
${ }^{1}$ Danjuma Abdullahi Phd, ${ }^{2}$ Zakariyau Yahaya Kwanga \\ ${ }^{1}$ College of law, government and international studies Universiti Utara, Malaysia \\ ${ }^{2}$ Department of Public Administration Waziri Umaru Federal Polytechnic Birnin Kebbi
}

\begin{abstract}
The paper intends to investigate the reasons for poor performance of local governments in Nigeria as well as looking at the alternative sources of funding local governments been the level of government closer to the people but unfortunately this level of government has been subjected to serious underfunding by the other tiers of government couple with economic recession that is affecting the globe, it is clear that government alone could no longer continuo funding local governments, Nigeria is a mono-crop economy that is heavily rely on oil, any fluctuation in the oil market could definitely make a negative impacts on their allocation and affect the rate of service delivery to the people, traditionally local government allocation came directly from federal allocation but for unknown reasons the state government do hijack it and gives local government a token amount that is not even enough for the payment of their salaries, Descriptive approach was used to gather data, the findings revealed poor performance of local governments in Nigeria and the paper suggest that local government should look outward for alternative sources of revenue instead of relying on federation allocation.
\end{abstract}

Key words: Local Government; Funding; Economy and Recession

\section{Introduction}

Local government is the most important tier of government among the three tiers being the closest to the people if well harness, funded and sustained. The purpose of this paper is to examine ways of diversifying the economy from relying on federation allocation to more vibrant tier of government. Local government council in Nigeria today relies heavily on federal allocation as their main source of revenue, how ever, no local government in Nigeria could sustained her self properly without the monthly allocation from the federation account beside Lagos and Kano state. Local government are far from being a place of developmental programmes, hence the rural populace are not feeling the impacts due to so many problems militating against the development of local government council. History has shown that local government over the years particularly during the civilian government 1999 to date had suffered from inadequate funding, mismanagement of public funds and inappropriate size of their area, executive control from the state government, over staffing, inappropriate organizational framework and lack of futurism in investment potentials which resulted in the administrative ineffectiveness, poor performance and low productivity. Joel, Alex and Mike (2001) opined that local government in Nigeria is the weakest among the three tiers of government due to inconsistent policy on the part of federal government to reduce the power of local government and resources which render them ineffective. The paper is divided into four parts. Part one is an introduction, part two examines the sources of revenue available to local governments in Nigeria, part three looks into problems of local government in Nigeria, part four identify the alternative sources of revenue to the local government and the last part offers conclusion and recommendation on how to improve local government administration in Nigeria.

\section{Sources of local government revenue in Nigeria}

Local government could source their monies from two sources that is internal and external. The external sources of revenue include the following:-

Statutory allocation from federation account : section 160(2) of 1999 constitution provided it as a major source of revenue to local government and it is the share of revenue from state/central government as fixed by law. It came into existence in order to replace block or general grant because of its inadequacies. Statutory revenue allocation was first introduced in Nigeria by the local government reform of 1976 as a means of providing adequate revenue to the local government. It is the local government share of the federation account and of the state government total revenue based on percentage formula in Nigeria, it is $20 \%$ of the federal account in addition to $10 \%$ of the total internal revenue of the state government unlike grants which are voluntary and depend on the whims and caprices of the state/central governments, statutory allocation is provided by law and hence mandatory for state/central government to pay. Moreover, grants are not fixed and hence they are quite flexible and uncertain. As revenue is definite and certain. Consequently, it ensures realistic 
budgeting and planning. An implication of this statutory revenue allocation is the recognition of local government as a level of government which has statutory and constitutional entitlement or right to a share of the national revenue, but over reliance on this source is the major problem of local governments in Nigeria. Banibo and Koroye (2011) added that for government to increased revenue generation, it must embark on entrepreneurial option of revenue generation, that is demanding for servicing of entrepreneurs in day to day activities of government which will eventually led to job creation instead of job seekers and consequently reduce the cost of governance.

Another source of revenue to the local government is the federal grants in aids which is a financial aid given by the central or state governments to the local government to enable it discharge it functions effectively. Traditionally grants in addition to assisting local government financially, it serve as an instrument of controlling, supervising and encouraging local governments.

Borrowing from state and other financial institution also constitute an integral part of external revenue. Local governments are empowered to raise loans for incurring capital development projects which are within their statutory functions such as market development, drainage scheme, health, education, agricultural and industrial development projects. Major capital development projects can be effectively financed through borrowing. Accordingly, no local governments can make giant stride in rapid community development without borrowing provided that there is an adequate security for the loans and that loans are prudently applied for the development project they are meant for.

The internal sources of revenue generation available to local government include:-

Local rate which is one of the internal source of local government revenue, although this source of revenue is not fetching any valuable revenue in Nigeria.

Another internal source of revenue is market tax. This is another important source of revenue generation but the pity of it is that is been subjected to private misappropriation by officers in-charge of it collection. According to Olaoye, Asaolu and Adewoye (2009) opined that dishonesty on the part of officers collecting the revenue such as printing additional receipts had rendered this source of revenue ineffective.

Other source includes fees and charges which are payment local governments impose for certain services which they provide. The fees are designed to regulate the services as well as provide funds for the local government. The imposition of fees and charges on any service by a local government requires an enabling bye -law for it to be lawful. Under market bye law, the local government charges fees on market stalls and lock-up stores. With appropriate bye laws, local government charges fees on motor parks. They can also issue a variety of licenses and charges fees on them. Fees are also charge on bakeries, sales or liquor, restaurants public eating house, the use of loudspeaker in public places and mounting of signboards through the issuing of licenses. Local government are empowered to register births, dearth and marriages and charge appropriate fees for them. The problem associated with these various fees particularly in developing nations like Nigeria is fee evasion and avoidance. Many citizens have not formed the habit of paying taxes, rate and fees very willingly. They prefer to cheat the government instead of paying financial impositions of any type to the government. On the other hand, most of these sources are scanty, under-developed or nonexistent in rural local government areas.

In addition, fine is another important source of revenue to the local government in Nigeria which are financial penalties imposed on individuals for a breach of bye-laws of the local government. Local government make bye law in order to regulate and control services allocated to them within their area of jurisdiction. Bye laws provide appropriate penalties in form of fines for their violation. Local government prosecutes individuals who violate their bye-laws in court where they could be fined. Local government in some nations of the world has their bye -laws. It is important to note that the revenue which the local government realizes from this source is generally insignificant.

Local government could also invest in commercial ventures and industrial establishments. Examples of such ventures are agricultural farms, soap industry, bakery, transportation service and others. The greatest merit of this source is thai it is based on ability to pay principle. Moreover, where the business is effectively managed without local authority interference and political interferences, huge revenue could be realized in continous basis. However the local government could be wrecked in business ventures where the business is not managed. This happens frequently when business is not managed along the business principles. For effective management of local government businesses, they should be hived from the local administration free from local authority interferences and partisan politics. They should be managed by relevant professional and technical experts and their personnel management governed by the merit principles Akindele, Olaopa and Sat (2002) agued that over reliance on allocation from the federal account, tax evasion by citizens, politic in local government creation, tempering with revenue rights of local government and responsibilities over whim the sources of revenue are some of the problems affecting local government.

Other sources includes gifts and donations, rents dividends and levies. The local government can receive gifts and donations from individuals and organizations. In Nigeria, local government as a mean to tap and exploit revenue from wealthy individuals in the society embark on various forms of launching of development projects. Usually the proceeds of such launchings are used for capital development projects. This 
type of sourcing funds should be encouraged since it is based on the principles of ability to pay and particularly on the willingness to pay. Local government can rent out their land or houses and collect rents from occupants. They can also invest in shares of viable and profitable companies from where they collect dividends. Local government with appropriate bye-law collect special levies within their areas of jurisdiction Olusola (2011) opined that issue of joint account and too much deductions by the state government, poor staffing, corruption among officials of local government, poor revenue generation, lack of accountability and insignificance sources of revenue are some of the problems.

Table 1 Local government sources of taxes

\begin{tabular}{|l|l|}
\hline S/N & \multicolumn{1}{|c|}{ SOURCE OF REVENUE } \\
\hline 1 & Shops and Kiosks rates \\
\hline 2 & Tenement rates \\
\hline 3 & On and off liquor licience fees \\
\hline 4 & Slaughter slab fees \\
\hline 5 & Marriage, birth and death registration fees \\
\hline 6 & Naming of street in the state capital \\
\hline 7 & Right of occupancy fees \\
\hline 8 & Market taxes and levies \\
\hline 9 & Motor park levies \\
\hline 10 & Domestic animal licience fees \\
\hline 11 & Bicycle, truck, canoe, wheelbarrow and Cart fee \\
\hline 12 & Merriment and road closure fee \\
\hline 13 & Vehicle radio licience fees \\
\hline 14 & Wrong parking charges \\
\hline 15 & Public convenience, sewage and refuse disporsal fees \\
\hline 16 & Customary burial ground permit fees \\
\hline 17 & Signboard and advertisement permit fees \\
\hline
\end{tabular}

Adapted from African Institute of applied economics 2012

The above table shows the internal sources of revenue available to local government, but the pity of it is that most of these sources are unharnessed and even where they are taped it been subjected to misappropriation by local government officials.

\section{Problems of revenue generation in local government in Nigeria}

Local government system in Nigeria face a number of problems especially with regard to revenue generation, some of these problems are as follows:-

Inter governmental relations between the three tiers of government placed local at disadvantage position. As a result of the relations between the three tiers of government especially the state- local relations rendered local government as just like mere agent of state government making it difficult for any developmental programmes to occur at local level, the method of election of local government chairmen which is been sponsor by state government making local government as a kind of puppet organization is a clear picture of how intergovernmental relations affects local government in Nigeria.

The poor state of economic and financial affairs of local government due to :

- Low revenue generation from internal source;

- Non implementation of relevant laws that gives powers to local government to raise revenue from other sources instead of over relaying on federal allocation.

- Non compliance of state governments to remit $10 \%$ of their internally generated revenue.

- Over dependence on the statutory allocations from federation account.

Table 2. Showing fluctuation on Local gov't. statutory allocation

\begin{tabular}{|l|l|l|l|l|}
\hline PERIOD & FED & STATE & LG & SPECIAL FUNDS \\
\hline 1981 & 55 & 35 & 10 & - \\
\hline 1989 & 50 & 30 & 15 & 5 \\
\hline 1993 & 48.5 & 24 & 20 & 7.5 \\
\hline 1994 & 48.5 & 24 & 20 & 7.5 \\
\hline 1999 & 48.5 & 24 & 20 & 7.5 \\
\hline 2002 & 56 & 24 & 20 & - \\
\hline 2004 & 52.68 & 26.72 & 20.60 & - \\
\hline
\end{tabular}




\begin{tabular}{|l|l|l|l|l|}
\hline 2012 & 52.68 & 26.72 & 20.60 & - \\
\hline
\end{tabular}

From the table above, it is clear that statutory allocation from federation account is fluctuating from 1981 to date moving inform of arithmetical progression.

Inelastic and unviable sources of internal revenue except property/tenement rates which very few local government tap from.

- Mis -management and misappropriation of scarce financial resources through:-

Inflation of contracts without following due process. According to Nigerian Abroad (2011) stated that:-

"Over the years there are indication that the hard-earned and limited resources accrued to and raised by local government are always mismanaged. Priorities are misplaced, projects are done not in accordance to or as demanded by the people but regrettably in tune with the selfish end and of the political leadership in collaboration with the senior bureaucrats at the local government level of administration".

- Fictitious expenses by senior officers and some chief executive such expenses include hospitality of visitors, Bills repairs of vehicles etc.

- Distotion of account and other financial records by staff and auditors.

- Dishonesty and false declaration of revenue collected by revenue collectors, officers and treasury staff.

\section{Alternative sources of funding local government in Nigeria}

Due to global economic depression in the global system to ensure sustainability of local government and effect service delivery, local governments in Nigeria need to develop alternative sources of funding such sources include

1. Private partnership through private cooperation local government could yield an important revenue. Kabir (2007) opined that local government can only function effectively in Nigeria through public and private partnership.

2. Also local government should hire independent body to oversee the collection of their independent taxes in order to promote efficiency. Bariyima and Gladson (2009) added that the only way out of financial mismanagement in local government is through use of tax consultants by the government.

3. Imposition of available taxes: Most of the internal sources of revenue available to the local government are unharnessed, tax evasion and subject to misappropriation by the officers in-charge. These sources of revenue could improve their revenue generation if well harnessed.

4. Adequate record: The essence of keeping record is to ensure transparency and accountability at local government level because poor record keeping is the root of financial crisis local governments are experiencing today.

5. Assigning roles and responsibilities to local communities, although due to economic recession going on in the globe today almost all institutions in Nigeria are facing the problem of funding, government alone could no longer continue providing goods and services to the people as a result through sharing of roles and responsibilities between local government and community might contribute greatly towards addressing financial problems facing local government in Nigeria Oviasuyi (2010) advocated that past government has neglected the rural communities with no significant developmental programmes to the people, he concluded that development could only occur at local government in Nigeria if there is involvement of local communities through sharing of responsibilities between the two parties.

6. Investment in viable areas so that to diversify the economy from mono-crop to over areas that are fetching. A clear picture of this is investment in area like building an estate that can accrue a lot of revenue to the local government.

\section{Conclusion}

There are many problems confronting local governments in Nigeria but inspite of the various ways adopted by government aimed at improving revenue opportunities for local government administration in Nigeria, the poor methods of internally generated revenue still remain problem that is bedeviling local governments in Nigeria.

\section{References}

[1]. Olaoye C.; Asaolu T.; Adewoye J.O. A review of revenue generation in Nigerian local government: A case study of Ekiti state. Medwell journals of international business management vol.3 pp 54-60 (2009). http/www.medwelljournalscom/fulltext.

[2]. Kabir M. Nigeria: Alternative for revenue sourcing for local government, weekly trust, 14 October 2007 (2007)http/allafrica.com/stories 2007

[3]. Bariyima D.; Gladson N. Boosting revenue generation by state governments in Nigeria, the tax consultant option revisited. European journal of social sciences, volume 8, number 4 (2009). http.www.eurojournal.com

[4]. African Institute of applied economics Budget and public expenditure across Nigerian states Becan working paper(2006) http/www.aiaenigeria.org/publication 
[5]. Olusola, O.O. Boosting internally generated revenue of local government in ogun state, Nigeria (A study of selected local governments in Ogun state). European journal of humanities and social sciences vol.8,No.1 p336-348 (2011)http/www.journalbank.com

[6]. Banabo E. and Koroye B. Stimulating internally generated revenue in Nigeria : The entrepreneurial option revisited. European journalof social sciences volume 23,number 4 p 520-530 (2011) http/www.eurojournal.com

[7]. Oviasuyi, P. O. Model for roles and involvement of local communities in development projects and programmes oflocalgovernmentauthorityinNigeria,journal of hum ecol 31(2) p 103-109 (2010). http/www.krepublishers.com.

[8]. Akindele S.T.; Olaopa O.R and Sat A.O. Fiscal federalism in Nigeria: A contemporary review Kamla Raj journal of social science 6(3) 215-235(2002) http/www.kreppublisher.com

[9]. Joel, D.B; Alex G. and Mike S. State and local government in Nigeria, public sector capacity building programme, African region, the world bank (2001). Retrieved from http/www. Wolrd bank.org/etools

[10]. Nigerian abroad Local government autonomy: Plausible panacea to grassroots challenges, September 132011 retrieved from http/ nigerianabroadlive.com 